\title{
Psychomotor Skills of Pre-service Teachers of Natural Science on Melde's Experiment in Guided Inquiry Learning
}

Septi Budi Sartika ${ }^{1}$, Noly Shofiyah ${ }^{2}$

1,2 Universitas Muhammadiyah Sidoarjo, Sidoarjo, Indonesia

\begin{tabular}{|c|c|}
\hline (A) Check for updates opery 0 access @c) & DOI : https://doi.org/10.46245/ijorer.v1i2.32 \\
\hline Article Info & ABSTRACT \\
\hline $\begin{array}{l}\text { Article history: } \\
\text { Submitted: June 10, 2020 } \\
\text { Final Revised: June 27, } 2020 \\
\text { Accepted: July 11, 2020 } \\
\text { Published Online: July 31, } 2020 \\
\text { Keywords: } \\
\text { Guided inquiry } \\
\text { Melde's Experiment } \\
\text { Natural science } \\
\text { Pre-service teachers } \\
\text { Psychomotor skills } \\
\square \\
\end{array}$ & $\begin{array}{l}\text { This research aimed to describe the psychomotor skills of pre-service } \\
\text { teachers of natural science on Melde's Experiment through guided } \\
\text { inquiry learning. Psychomotor skills were assessed by observation } \\
\text { during students conduct the Melde' s experiment. This research } \\
\text { method used was descriptive quantitative in which the authors } \\
\text { described the research variables from the collected data. The study } \\
\text { was conducted on a pre-service natural science teacher who learns the } \\
\text { Optic and Geometry Course. The data analysis uses descriptive } \\
\text { statistical. The results showed that the psychomotor skills of pre- } \\
\text { service teachers of natural science are categorized as very good in } \\
\text { manipulation, good in precision and articulation; fair in imitation and } \\
\text { naturalization domain. Thelowestcategory of psychomotor indicators is } \\
\text { naturalization. Naturalization is doing related activities according to } \\
\text { the skills that are owned, a sample designing experiment with } \\
\text { different variables. Different variables with the module make the } \\
\text { prospective teacher's students think hard to create the experimental } \\
\text { draft, consequently, the experimental design and findings are not equal } \\
\text { to the theory. Further research is expected to have a learning model } \\
\text { that is capable of training better psychomotor skills. }\end{array}$ \\
\hline
\end{tabular}

\section{INTRODUCTION}

The classroom offers extensive knowledge to help students understand scientific and everyday life phenomena Susantini et al. (2018). Applying guided inquiry learning can improve the psychomotor domain science process skills in activities setting Anjarwani et al. (2020). Psychomotor knowledge is one aspect of ability in addition to cognitive and affective. According to Rosa (2015), the psychomotor domain is a domain related to skills or ability to act after a person receives a specific learning experience. Learning that refers to the 2013 Curriculum is also required to be a student-centered activity, so that students have the opportunity to explore their abilities, (Anikarnisia \& Wilujeng, 2020). This psychomotor domain is measured by observing and assessing the skills of the students while conducting experiments, but this ability is rarely revealed.

The invention of something is done with the based guided inquiry learning models. Science education in the modern era focusing on the ability of students to be active in the learning process through the exploration process. Specifically, the current education tries to help students learn to organize and construct opinions, formulate problems, develop hypotheses, and look for evidence himself Nisa et al. (2018). The teaching-learning models are quite effective in improving psychomotor skills as evidenced by the medium-category improvement score and a very strong response 
Patimapat et al. (2019). This is in line with the research results of Sugiarti (2018) that the psychomotor skills of the students experienced an increase with the guided inquiry models. The following results of the study of Sulawanti et al. (2019) that there is a significant influence on the implementation of a laboratory-based inquiry model for psychomotor ability. Thus the guided inquiry models can be used as an alternative solution in revealing the concept of natural science.

In science learning, practicum is the best method to acquire a better understanding of the science concept and application. The laboratory-based learning supports students to invention the facts and theories of science. However, the psychomotor skills are also important since science is not only about the knowledge, but also the human application skills of motor skills, such as tools stringing and measurement. These abilities are also beneficial for learners in everyday life. Practicum aims to increase the conceptual understanding and students' psychomotor skills Millar \& Abrahams (2009). Generally, research on psychomotor is conducted in health education, especially nursing Lopes et al. (2019), Rourke (2019), Nicholls et al. (2018). Supported by the opinions of Hofstein \& Lunetta (2004), science learning is less successful if it is not supported by the practical activities.

The practical activities of students in the laboratory are linked with the psychomotor domain. This domain emphasis on manual task that involves the objects manipulation and physical activities Merrit (2008). According to Zaghloul (2001) and Merrit (2008), when students perform those activities, their mind and body are linked together. Krathwohl \& Anderson (2009) have introduced five levels of psychomotor domain hierarchy related to laboratory experiments in natural science education refer to Table 1.

Table 1. Psychomotor domain.

\begin{tabular}{ll}
\hline \multicolumn{1}{c}{ Indicator } & \multicolumn{1}{c}{ Description } \\
\hline Imitation & Impersonate another person's actions, impersonate the replicate. \\
Manipulation & Reproduce the command of the teacher or its memory. \\
Precision & Perform skills without the help of others. \\
Articulation & Adapt or integrate expertise. \\
Naturalization & Doing related activities according to the skills already have. \\
\hline
\end{tabular}

One of the concepts in Science that is accustomed to being taught in laboratory activities is Melde's Law. Melde's Law is a law that explains the concept of wave propagation in a string. Melde's Experiment is carried out to prove what physical quantities affect the wave velocity of a string. Where the wave velocity at the string is proportional to the root of the tension force and is inversely proportional to the root mass per unit length of the string (Bozzo et al, 2019).

In the Melde's Experiment, many psychomotor skills were performed by the students. One of them is the skill of installing string, pulley, weight, generator, and vibrators into a correct circuit. However, these skills are rarely assessed by the teacher. The teacher only assessed the results of the practicum report or the student's worksheet Nugraha et al. (2018) \& Nugraha et al. (2019). The teachers rarely assess how students perform during an experiment. This is supported by several previous studies which stated that the most common assessment method that was used in the laboratories was the written laboratory report Salim et al. (2012). The lack of written reports is not being 
able to measure the practical skills demonstrated by students Pickford \& Brown (2006). Melde's Experiment can be integrated into learning by using the inquiry-based learning model. Inquiry can be defined as "the intentional process of diagnosing problems, critiquing experiments, and distinguishing alternatives, planning investigations, researching conjectures, searching for information, constructing models, debating with peers, and forming coherent arguments" Linn et al. (2004). Guided Inquiry Learning is one of the learning strategies focused on a research-based, student-centered philosophy and science pedagogy.

Students work in small groups to engage in guided inquiry using carefully designed materials that direct and guide students to build and rebuild their science knowledge Barthlow \& Watson (2014). Through inquiry, students are prompted to resolve the problem, or else to discover the answer Vlassi \& Karaliota (2013). Simonson \& Shadle (2013) states that guided inquiry is a comprehensive learning model for students since they can work individually or in groups to investigate a topic. The Implementation of guided inquiry learning can improve the psychomotor domain of science process skills in activities setting Anjarwani et al. (2020). Villagonzalo (2014) also revealed that guided inquiry learning is an effective method in fostering students' academic performance than traditional strategies of teaching. Based on the explanation stated before, this study aims to examine the students' psychomotor skills through the implementation of guided inquiry learning in the Melde's Experiment. The expected benefit of this research is to expand the knowledge about the psychomotor skills of students during Melde's Experiment.

\section{RESEARCH METHOD}

This research method used was descriptive quantitative in which the authors described the research variables from the collected data. The study was conducted on pre-service natural science teachers who learn the Optic and Geometry Course, namely as many as 23 students in the seventh year of the study. The students were asked to conduct Melde's Experiment with the experimental design as shown in Figure 1.

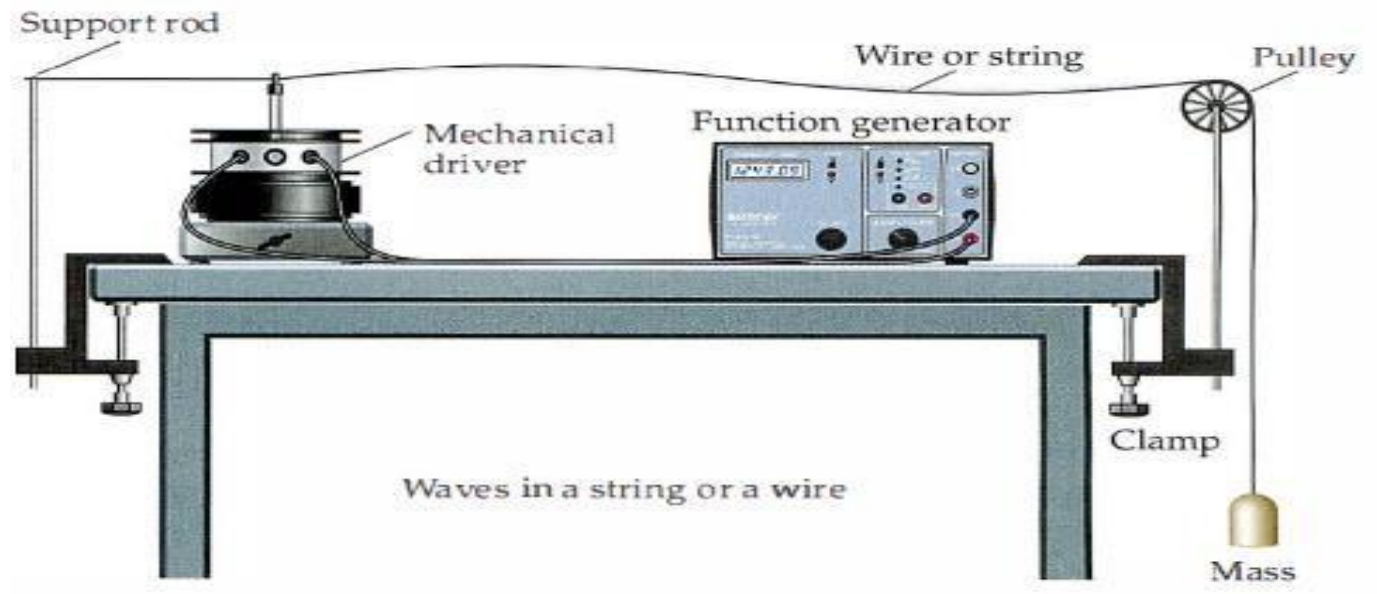

Figure 1. The design of Melde's Experiment.

The psychomotor skills of students were assessed during the implementation of guided inquiry learning with Melde's Experiment. The data were collected using 
observation sheets of the guided inquiry learning, activity sheets learners about the psychomotor skills and documentation.

The observation sheets of the guided inquiry learning include 1) drawing the attention and explaining the inquiry process; 2) presenting inquiry problems;3) asking students to formulate hypotheses; 4) guiding students to collect data to test hypotheses; 5) make explanations or conclusions; and 6) reflecting the problem situation. Meanwhile, the activity sheet of the psychomotor skills includes 5 indicators namely 1) imitation, 2) manipulation, 3) precision, 4) articulation, and 5) naturalization. The activities measured for each psychomotor indicator can be seen in Table 2.

Table 2. Activities of psychomotor.

\begin{tabular}{|c|c|}
\hline Indicator & Description \\
\hline Imitation & $\begin{array}{l}\text { Emulate the actions of the teacher/ laboratory assistant steps in the } \\
\text { collection of experimental data. }\end{array}$ \\
\hline Manipulation & Conduct experiments following the variables in the lab module. \\
\hline Precision & Demonstrate expertise using measuring instruments without assistance. \\
\hline Articulation & $\begin{array}{l}\text { Associate a combination of practicum activity by developing science process } \\
\text { skills. }\end{array}$ \\
\hline Naturalization & Conduct activities with the strategy according to the needs. \\
\hline
\end{tabular}

Profile of every aspect of psychomotor skills is measured processed and made a percentage by interpretation as shown in Table 3.

Table 3. Percentage interpretation of psychomotor skills.

\begin{tabular}{cc}
\hline Percentage & Categorized \\
\hline $81-100$ & Very Good \\
$71-80$ & Good \\
$61-70$ & Fair \\
$51-60$ & Poor \\
$0-50$ & Very Poor \\
\hline
\end{tabular}

\section{RESULTS AND DISCUSSION}

The results of research conducted are psychomotor skills of students of natural science preservice teachers in Melde's Experiment Table 4:

Table 4. Psychomotor skills results.

\begin{tabular}{lll}
\hline Indicator & Score & Categorized \\
\hline Imitation & 88 & Very Good \\
Manipulation & 80 & Good \\
Precision & 75 & Good \\
Articulation & 70 & Fair \\
Naturalization & 63 & Fair \\
\hline
\end{tabular}

Based on Table 2 it can be obtained that the imitation indicator obtains the highest category is very good, as the articulation and naturalization indicator is gaining the lowest category is fair. This category may indicate psychomotor skills for natural science 
preservice teachers in Melde's Experiment are well. It complies with the results of the observation of the implementation of experimentation Melde's Law through guided inquiry model carried out excellent, which starts from the syntax of 1 to 6 with an average score of 3.8. The guided inquiry learning models is a model very close to the principle of constructionist, which explains that knowledge is constructed by learners. It is important that in the model of inquiry content and the investigation process are taught together in an ongoing time. In the investigation process finally, students can find the knowledge content learned.

Based on the results of research gained that imitation indicators with very good categories. Imitation is the ability to emulate the actions of others. One of the mimicking activities undertaken by the students is the fact that they are a tool for experiments in the laboratory of Melde's Law. In this case, the average student can do well-related skills in linking the loads hung with the vibrator using a rope. The ability to emulate this is a psychomotor skill that is easiest to do compared to other skills because it only mimics the tool's arrangement according to the experimental design. According to Noorhidawati et al. (2015), imitation is the ability to perform simple activities and the same as seen or noted before. Another indicator of psychomotor skills is manipulation.

In manipulation indicators, students are required to formulate problems, hypotheses, and experimental variables. At the Melde's Experiment, students can determine the variable manipulation, response, and control according to the formulation of the problem made. For example, if the problem is how the effect of the hanging load on the number of waves formed (wavelength), then the manipulation variable is the load mass, the response variable is the wavelength, and the control variable is a long rope, rope type, and frequency of vibrator. Through this Melde's Experiment, the average student has been able to create a variety of experimental variables correctly. According to Dewi et al. (2017), The inquiry model can develop a student science process skills indicator, namely predicting, formulating hypotheses, and variable identification.

Another indicator of psychomotor skills is precision. Precision demonstrates the skill of using measuring instruments without help. In Melde's Experiment, students are required to use vibrator and voltage sources. Vibrators are a tool that generates vibrations when connected to a voltage source. The results of the student's assessment of the vibrator and the voltage source and use it demonstrates that the average student is already able to use it properly. Rustaman (2005) explained that one of the generic skills in natural science in college is aware of the scale of magnitude (sense of scale) of measuring instruments. Measuring activities can be slipped to give to students when they perform data analysis activities (Adirahayu \& Wulandari, 2019).

The next indicator is the articulation. Articulation associates a combination of experiment activity by developing science process skills. In Melde's Experiment, students are required to repeat experiments with the same variables. In this aspect, students obtain a good category. Banjarnahor et al. (2016), through his research also showed that the articulation aspects of students in the category were less good.

The lowest category of psychomotor indicators is naturalization. Naturalization is doing related activities according to the skills that are owned, a sample designing experiment with different variables. Different variables with the module make the 
prospective teacher's students think hard to create the experimental draft, consequently, the experimental design and findings are not equal to the theory. According to Nurhikmah (2014), naturalization is the ability to perform reflex activities that involve physical activities that require high working effectiveness. Guided inquiry models make it possible to prove Melde's equation through experimentation. This is in accordance with the results of the research of Nugraha et al. (2019) that model of modification inquiry learning to affect the psychomotor skills of students, as well as results of the research Prihatiningtyas et al. (2013) inquiry learning models assisted module practicum can improve students' psychomotor skills.

\section{CONCLUSIONS}

Based on the results and analysis of data can be concluded that the psychomotor skills of pre-service teachers of natural science are categorized as very good in manipulation, good in precision and articulation; fair in imitation and naturalization domain. The lowest category of psychomotor indicators is naturalization. Naturalization is doing related activities according to the skills that are owned, a sample designing experiment with different variables. Different variables with the module make the prospective teacher's students think hard to create the experimental draft, consequently, the experimental design and findings are not equal to the theory. Further research is expected to have a learning model that is capable of training better psychomotor skills.

\section{ACKNOWLEDGEMENTS}

The author realizes the support of leadership, superiors, and associates, the author thanked:

1. Dr. Akhtim Wahyuni, M.Ag, Dean of the Fakultas Psikologi dan Ilmu Pendidikan.

2. All the academic in Program Studi Pendidikan IPA, Lecturers, and Students that have provided the support of the authors.

\section{REFERENCES}

Adirahayu, M.F., \& Wulandari, F.E. (2019). Model pembelajaran inkuiri terbimbing dan pengaruhya terhadap keterampilan proses sains siswa. Science Education Journal, 2(2), 101-107.

Anikarnisia, N. M., \& Wilujeng, I. (2020, January). Need assessment of STEM education based on local wisdom in junior high school. Journal of Physics: Conference Series, 1440, 012092.

Anjarwani, R., Doyin, M., \& Indiatmoko, B. (2020). Guided inquiry learning with outdoor activities setting to improve critical thinking ability and science process skills of elementary school students. Journal of Primary Education, 9(2), 129-135.

Banjarnahor, J., Natalina, M., \& Nursal, N. Profil kemampuan siswa SMP dalam menyelesaikan soal Uji Kompetensi Laboratorium (UKL) pada kegiatan Pekan Raya Biologi (PRB) 2016. Doctoral Dissertation. Riau: Riau University.

Barthlow, M.J., \& Watson, S.B. (2014). The effectiveness of process-oriented guided inquiry learning to reduce alternative conceptions in secondary chemistry. School Science and Mathematics, 114(5), 246-255. 
Dewi, E. P., Suyatna, A., Abdurrahman, A., \& Ertikanto, C. (2017). Efektivitas Modul dengan Model Inkuiri untuk Menumbuhkan Keterampilan Proses Sains Siswa pada Materi Kalor. Tadris: Jurnal Keguruan dan Ilmu Tarbiyah, 2(2), 105-110.

Hofstein, A., \& Lunetta, V.N. (2004). The laboratory in science education: Foundations for the twenty-first century. Science Education, 88(1), 28-54.

Krathwohl, D.R., \& Anderson, L.W. (2009). A taxonomy for learning, teaching, and assessing: A revision of Bloom's taxonomy of educational objectives. New York: Addison Wesley Longman, Inc.

Linn, M.C., Davis, E.A., \& Bell, P. (2004). Inquiry and technology. Internet Environments for Science Education, 3-28.

de Lima Lopes, J., Baptista, R. C. N., Lopes, C. T., Rossi, M. B., Swanson, E. A., \& de Barros, A. L. B. L. (2019). Efficacy of a video during bed bath simulation on improving the performance of psychomotor skills of nursing undergraduates: A randomized clinical trial. International journal of nursing studies, 99, 103333.

Merrit, R.D. (2008). The psychomotor domain. EBSCO Research Starters.

Millar, R., \& Abrahams, I. (2009). Practical work: Making it more effective. School Science Review, 91(334), 59-64.

Nicholls, D., Sweet, L., Muller, A., \& Hyett, J. (2018). A model to teach concomitant patient communication during psychomotor skill development. Nurse Education Today, 60, 121-126.

Nisa, E. K., Koestiari, T., Habibbulloh, M., \& Jatmiko, B. (2018, March). Effectiveness of guided inquiry learning model to improve students' critical thinking skills at senior high school. In Journal of Physics: Conference Series, 997, 012049.

Nugraha, M. G., Utari, S., Saepuzaman, D., \& Nugraha, F. (2018, May). Redesign of students' worksheet on basic physics experiment based on students' scientific process skills analysis in Melde's law. In Journal of Physics: Conference Series, 1013, 012038.

Nugraha, M. G., Utari, S., Saepuzaman, D., Solihat, F. N., \& Kirana, K. H. (2019, November). Development of basic physics experiments based on science process skills (SPS) to enhance mastery concepts of physics pre-service teachers in Melde's law. In Journal of Physics: Conference Series, 1280, 052075.

Nurhikmah, n. (2015). Pengaruh model STM (Sains, Teknologi, Masyarakat) berbasis scientific terhadap kompetensi kognitif, psikomotor, dan afektif siswa kelas XI MIA pada mata pelajaran biologi di SMA Negeri 4 Purwokerto tahun pelajaran 2014/2015. Doctoral Dissertation. Purwokerto: Universitas Muhammadiyah Purwokerto.

Noorhidawati, A., Ghalebandi, S.G., \& Hajar, R.S. (2015). How do young children engage with mobile apps? Cognitive, psychomotor, and affective perspective. Computers $\mathcal{E}$ Education, 87, 385-395.

Patimapat, M., Duda, H.J., \& Supiandi, M.I. (2019). Efektivitas model pembelajaran inkuiri terbimbing melalui metode demonstrasi terhadap hasil belajar psikomotorik siswa. JPBIO: Jurnal Pendidikan Biologi, 4(1), 9-20.

Pickford, R., \& Brown, S. (2006). Assessing Skills and Practice. New York: Routledge. Prihatiningtyas, S., Prastowo, T., \& Jatmiko, B. (2013). Imlementasi simulasi PhET dan KIT sederhana untuk mengajarkan keterampilan psikomotor siswa pada pokok bahasan alat optik. Jurnal Pendidikan IPA Indonesia, 2(1), 1-10. 
Rosa, F. O. (2015). Analisis Kemampuan Siswa Kelas X pada Ranah Kognitif, Afektif dan Psikomotorik. Omega: Jurnal Fisika dan Pendidikan Fisika, 1(2), 2428.

Rourke, S. (2020). How does virtual reality simulation compare to simulated practice in the acquisition of clinical psychomotor skills for pre-registration student nurses? A systematic review. International Journal of Nursing Studies, 102, 103466.

Rustaman, N.Y. (2005). Perkembangan penelitian pembelajaran berbasis inkuiri dalam pendidikan sains. In Makalah dipresentasikan dalam Seminar Nasional II Himpunan Ikatan Sarjada dan Pemerhati Pendidikan IPA Idonesia Bekerjasama dengan FPMIPA. Universitas Pendidikan Indonesia, 22-23.

Salim, K.R., Puteh, M., \& Daud, S.M. (2012). Assessing students practical skills in basic electronic laboratory based on psychomotor domain model. ProcediaSocial and Behavioral Sciences, 56, 546-555.

Simonson, S. R., \& Shadle, S. (2013). Implementing process oriented guided inquiry learning (POGIL) in undergraduate biomechanics: Lessons learned by a novice. Journal of STEM Education: Innovations and Research, 14(1), 1-10.

Sugiarti, S. (2018). Penilaian psikomotor siswa pada pembelajaran fisika melalui model pembelajaran guided inquiry. PASCAL (Journal of Physics and Science Learning), 2(1), 78-84.

Sulawanti, E.V., Ramdani, A., Bahri, S., \& Merta, I.W. (2019). Pengaruh Penerapan Model Pembelajaran Inkuiri Berbasis Laboratorium Terhadap Kemampuan Psikomotorik Siswa. Jurnal Pijar MIPA, 14(3), 141-147.

Susantini, E., Sumitro, S.B., Corebima, A.D., \& Susilo, H. (2018). Improving learning process in genetics classroom by using metacognitive strategy. Asia Pacific Education Review, 19(3), 401-411.

Villagonzalo, E.C. (2014). Process oriented guided inquiry learning: An effective approach in enhancing students academic performance. DLSU Research Congress, 2, 1-6.

Vlassi, M., \& Karaliota, A. (2013). The comparison between guided inquiry and traditional teaching method. A case study for the teaching of the structure of matter to 8th grade Greek students. Procedia-Social and Behavioral Sciences, 93, 494-497.

Bozzo, G., de Sabata, F., Pistori, S., \& Monti, F. (2019). Imaging and studying standing waves with a homemade Melde-type apparatus and information and communication technology (ICT). The Physics Teacher, 57(9), 612-615.

Zaghloul, A.R.M. (2001). Assessment of lab work: a three-domain model; cognitive, affective, and psychomotor. Age, 6(1), 1-10. 
*Septi Budi Sartika (Corresponding Author)

Program Study of Natural Science Education,

Universitas Muhammadiyah Sidoarjo,

Jl. Mojopahit 666 B Sidoarjo, East Java, Indonesia

Email: septibudi1@umsida.ac.id

\section{Noly Shofiyah}

Program Study of Natural Science Education,

Universitas Muhammadiyah Sidoarjo,

Jl. Mojopahit 666 B Sidoarjo, East Java, Indonesia

Email: nolyshofiyah@umsida.ac.id 